\title{
Effects of Different Seed Coating Ratios of an Organic Acid Mixture on Yield and Quality of Bread Wheat
}

\author{
Hatun Barut $^{1 *}$, Sait Aykanat, Ali Alpaslan Ezici, Uğur Sevilmiş
}

Eastern Mediterranean Agricultural Research Institute, 01370 Doğankent/Yüreğir/Adana, Turkey

\section{A R T I C L E I N F O}

\section{Research Article}

Received 17 August 2018

Accepted 03 October 2018

Keywords:

Bread wheat

Seed coat

Organic acids

Yield

Quality

*Corresponding Author:

E-mail: baruthatun@yahoo.com

A B S T R A C T

This research was conducted during 2016-2017 awheat growing season to investigate the effects of different rates of seed coating of an organic acid mixture (citric acid, glutamate, and proline) on yield and quality of wheat. The field experiments were established in Dogankent and Haciali locations of Eastern Mediterranean Agricultural Research Institute in Turkey. Study was carried out with randomised complete block design with 4 replications and Ceyhan-99 bread wheat variety was used as seed material. Before seeding, wheat seeds were coated with organic acid mixture product $(0.75 \%$ citric acid, $0.25 \%$ glutamate, $0.25 \%$ proline, $2 \% \mathrm{Zn}$ and 96.75 water), in three different doses (500 $\mathrm{ml}$ ton $^{-1}, 11$ ton $^{-1}, 1.51$ ton $^{-1}$ ) to compare with control (uncoated). There were statistically significant differences at 5\% level in 1000 grain weight and grain yield values in Dogankent location and 1000 grain weight, grain yield and number of spikes in Hacialilocation. Highest yield values were obtained from $500 \mathrm{ml} \mathrm{t}^{-1}$ application dose for both locations. With $500 \mathrm{ml} \mathrm{t}^{-1}$ application dose at Dogankent location, grain yield was $11.9 \mathrm{t} \mathrm{ha}^{-1}$ which was $8.97 \%$ higher over control. In Hacali location, $500 \mathrm{ml} \mathrm{t}^{-1}$ application dose was increased yield by $15.96 \%$ compared to control which resulted with $10.5 \mathrm{t} \mathrm{ha}^{-1}$ grain yield. No statistically significant difference was observed in quality characteristics (protein, gluten, hardiness and sedimentation) in trials.

DOI: https://doi.org/10.24925/turjaf.v6i11.1662-1667.2187

\section{Introduction}

World wheat production has a share of $25.9 \%$ among cereals with a value of 728 million tons in 2016. Wheat production was ranked third in the world among grains after corn and rice. $70 \%$ of world wheat acreage is in US, Australia, India, China, Russia, Kazakhstan, Canada, Pakistan and Turkey. Turkey was the $9^{\text {th }}$ country based on acreage with $3,5 \%$ in the world (FAO, 2016). As the production areas are limited, the probable ways to increase wheat production are breeding, using appropriate seeds, raising awareness of producers and making balanced fertilization at the appropriate time.

Good germination and stand establishment are maximizing factors in crop production, which is well recognized by farmers (Yariet et al., 2011). In modern agriculture, fungicides, herbicides, insecticides and plant growth stimulants are commonly used (Calvo et al., 2014). New group of products like bio stimulants are used to maximize crop yield and quality, especially under unfavourable environmental conditions. These products are also safe for the environment (Du Jardin, 2015). The application of amino acids allows plants to save energy and increase their development especially during critical times of plant development (Seadh et al., 2008).

Coating seed with nutrients is a method used to increase early plant growth. Seed coating is the process of applying exogenous materials to the seed coat. This practice is used to modify the physical properties of seed and for the delivery of active ingredients. Introduction of seed coating technology in developing countries is expected to increase global market to $\$ 1.6$ billion year ${ }^{-1}$ by 2020 (Pedrini et al., 2017).

Osmoprotectants like proline are low molecular weight, soluble organic compounds which are usually non-toxic at high cellular concentrations. These provide protection to plants from stress by helping to cellular osmotic adjustment, Reactive Oxygen Species detoxification, protection of membrane integrity and enzymes/protein stabilization (El Sayed et al., 2015). Natural accumulation of proline/betaine, however, is not high enough to protect plants from stress-induced damage (Subbarao et al., 2001). Glutamate and glutamine are the first organic nitrogen compounds derived from the assimilation of nitrate and ammonium in plants (Tabuchi et al., 2007). Glutamate inhibits primary root growth and stimulates the outgrowth of lateral roots near the primary root tip in Arabidopsis (Walch-Liu et al., 2006). Exogenous citric acid may ameliorate micronutrient deficiencies calcareous soils (Ferreyra et al., 1998). Citric acid makes complexes with $\mathrm{Al}, \mathrm{Fe}, \mathrm{Mn}$, and $\mathrm{Cu}$ in soils (Campbell, 2010). Sánchez-Rodríguez et al. (2014) informed that a mixture of oxalic, malic and citric acid at $10 \mathrm{mM}$ concentration decrease iron chlorosis on 
calcareous soils in chickpea. Also, Ström et al. (2005) report that the nutrient extraction efficiency increases through the application of citric acid $(10 \mathrm{mM})$. MartinezPacheco et al. (2011) reported that citric acid differentially induced proteolytic activity and vigor in the corn hybrids. Sadak et al. (2013) reported that coapplication of ascorbic acid and citric acid may alleviate the harmful effects of salinity stress.

The objective of this study was to determine the effect of seed coating of citric acid, proline and glutamate mixture on grain yield of wheat under field conditions.

\section{Material and Methods}

\section{Experimental Site}

The experiments were established in Eastern Mediterranean Agricultural Research Institute in Dogankent and Haciali locations in Turkey. Soil samples were collected and analysed before sowing the field to determine the productivity and micro-element contents. Soil analysis results of Dogankent and Haciali locations are given in Table 1 .

Soil of Dogankent location is mild alkali-salt-free and clay-loamy structured. Lime and iron content were high; potassium and copper content were adequate; organic matter, phosphorus, manganese and zinc content were low in this location. Hacali location were light alkali-salt-free and clayed structured. Lime, potassium and iron were high; the organic matter and copper were sufficient; phosphorus, manganese and zinc were low in this location.

Soil available $\mathrm{P}$ content was determined in parallel with the methods of Olsen et al. (1954). Soil pH was determined by using a digital $\mathrm{pH}$ meter from soil saturation extract (Jackson, 1959). Soil organic matter content was determined by using Walkey-Black wetetching method (Jackson, 1959). Sand, silt and clay fractions were determined by using Hydrometer method (Bouyoucus, 1952). Soil lime content was measured with a Scheibler calcimeter. Soil salt content was measured in saturation paste with Wheat stone bridge method (US Salinity Laboratory Staff, 1954).

\section{Climatic Characteristics of the Research Site}

The climatic characteristics between November 2016 and May 2017 during wheat growing season in Çukurova region are given below. While the average amount of rainfall that Adana received during the wheat growing season was about $550 \mathrm{~mm}$ for long years, Dogankent location and Haciali location received $572.6 \mathrm{~mm}$ and $396.7 \mathrm{~mm}$ rainfall respectively during trial season. The climatic values of Dogankent and Haciali locations are given in Table 2 .

Total amount of rainfall received by Dogankent location was $45.48 \mathrm{~mm}$ higher than long term average. Relative humidity values were higher in all months compared to long term averages. Average monthly temperature values were close to long term averages for all months. In Hacali location, the total amount of rainfall was $130.4 \mathrm{~mm}$ less than the average of long term average. Relative humidity values were higher in all months except February when compared to long term averages. Average temperature values were close to long years where values were lower in all months except March.

\section{Plant Materials}

Ceyhan-99 bread wheat variety was used as seed material which is a commonly preferred variety for farmers in Cukurova region. This was developed by the Eastern Mediterranean Agricultural Research Institute.

\section{Methods}

Experiments were conducted in two locations in randomized blocks trial design with four replications. In both locaitons, 450 seeds $\mathrm{m}^{-2}$ sowing norm was applied. The size of the experimental plots was $1.4 \mathrm{~m}$ in width and $5 \mathrm{~m}$ in length. organic acid mixture product contains $0.75 \%$ citric acid, $0.25 \%$ glutamate, $0.25 \%$ proline, $2 \%$ $\mathrm{Zn}$ and 96.75 water. This product was used for seed coating before sowing. Recommended application rate is $8.5 \mathrm{~g} 100$ cereal grains $^{-1}$ according to producer company (Anonymus, 2018). Four different coating ratios (0.5 1 ton $^{-1}, 11$ ton $^{-1}$ and 1.51 ton $^{-1}$ ) were used in the study. There was no seed coating for control applications.

Table 1 Soil analysis results of Dogankent and Haciali locations

\begin{tabular}{|c|c|c|c|c|c|c|c|c|c|c|c|c|}
\hline \multirow{2}{*}{ Location } & \multicolumn{2}{|c|}{ Saturation } & \multirow{2}{*}{$\frac{\mathrm{pH}}{(1: 2.5)}$} & \multirow{2}{*}{$\frac{\text { Salt }}{(\%)}$} & \multirow{2}{*}{$\frac{\text { Lime }}{(\%)}$} & \multirow{2}{*}{$\frac{\text { O. M. }}{(\%)}$} & \multirow{2}{*}{\multicolumn{2}{|c|}{$\frac{\mathrm{P}_{2} \mathrm{O}_{5} \quad \mathrm{~K}_{2} \mathrm{O}}{\left(\mathrm{kg} \mathrm{ha}^{-1}\right)}$}} & $\mathrm{Zn}$ & $\mathrm{Fe}$ & $\mathrm{Cu}$ & $\mathrm{Mn}$ \\
\hline & $(\%)$ & Class & & & & & & & \multicolumn{4}{|c|}{$\left(\mathrm{mg} \mathrm{kg}^{-1}\right)$} \\
\hline Dogankent & 63 & $\mathrm{CL}$ & 7.98 & 0.037 & 18.73 & 1.96 & 28.5 & 469.2 & 0.42 & 6.62 & 0.98 & 5.58 \\
\hline Haciali & 73 & $\mathrm{C}$ & 7.98 & 0.060 & 19.00 & 2.42 & 33.1 & 725.8 & 0.22 & 7.39 & 1.34 & 4.36 \\
\hline
\end{tabular}

Table 2 Climatic characteristics of Dogankent and Haciali locations in 2016-2017 wheat growing season

\begin{tabular}{|c|c|c|c|c|c|c|c|c|c|}
\hline \multirow[t]{2}{*}{ Month } & \multicolumn{3}{|c|}{ Average Temperature $\left({ }^{\circ} \mathrm{C}\right)$} & \multicolumn{3}{|c|}{ Total Precipitation (mm) } & \multicolumn{3}{|c|}{ Relative Humidity (\%) } \\
\hline & LT & Doğankent & Hacıali & $\mathrm{LT}$ & Doğankent & Hacıali & LT & Doğankent & Haciali \\
\hline November & 14.90 & 12.93 & 14.74 & 77.38 & 24.80 & 28.90 & 63.61 & 66.87 & 66.87 \\
\hline December & 10.52 & 7.34 & 9.60 & 118.27 & 261.20 & 66.00 & 67.06 & 80.69 & 89.60 \\
\hline January & 9.22 & 6.96 & 7.30 & 94.07 & 75.60 & 98.20 & 64.91 & 77.56 & 72.10 \\
\hline February & 10.02 & 9.04 & 9.40 & 84.14 & 3.60 & 6.60 & 63.02 & 63.26 & 58.10 \\
\hline March & 13.02 & 13.37 & 13.70 & 62.61 & 84.40 & 103.40 & 65.13 & 78.61 & 72.80 \\
\hline April & 17.27 & 16.91 & 17.20 & 50.17 & 74.40 & 72.20 & 66.77 & 73.72 & 69.40 \\
\hline May & 21.45 & 20.10 & 19.70 & 40.48 & 48.60 & 21.40 & 66.04 & 81.62 & 79.20 \\
\hline Total & & & & 527.12 & 572.60 & 396.70 & & & \\
\hline
\end{tabular}


Determination of the conventional fertilizer requirement was calculated according to the plant species and pre-sowing soil analysis. $70 \mathrm{~kg} \mathrm{ha}^{-1}$ of phosphorus $\left(\mathrm{P}_{2} \mathrm{O}_{5}\right)$ and a total of $160 \mathrm{~kg} \mathrm{ha}^{-1}$ of nitrogen (in the form of DAP and Urea) were applied to plots. Nitrogen was applied at sowing and tillering stages of crop. Effect of applications on plant height, number of spikes per $\mathrm{m}^{2}$, 1000 grain weight, hectolitre weight and yield values of bread wheat was investigated. In addition, gluten content, protein content, hardness and sedimentation analyses were performed on harvested grains.

\section{Statistical Analyses}

The analysis was performed using analysis of variance (ANOVA). Experimental results were subjected to LSD test using JUMP statistical software.

\section{Result and Discussion}

The effects of seed coating with different doses of organic acid mixture on some agronomic characteristics of wheat were investigated by the experiments carried out in Dogankent and Hacali locations of the Eastern Mediterranean Agricultural Research Institute of Turkey.

As a result of the observations and variance analysis (Table 3), it was determined that there was no statistical difference in plant height, number of spikes (number $\mathrm{m}^{-2}$ ) and hectolitre weights in Dogankent location. Statistically significant differences were observed in 0.05 significance level in terms of 1000 grain weight and grain yield in same location. Differences were subjected to the LSD test and are given in Table 3, 4 .

Table 3 Variance analysis of applications in Dogankent location (Mean Square)

\begin{tabular}{l|cccccc}
\hline \multicolumn{1}{c|}{ Source } & DF & $\begin{array}{c}\text { Plant Height } \\
(\mathrm{cm})\end{array}$ & $\begin{array}{c}\text { Number of Spikes } \\
\left(\text { piece m }^{-2}\right)\end{array}$ & $\begin{array}{c}\text { Hektoliter Weight } \\
(\mathrm{kg})\end{array}$ & $\begin{array}{c}\text { 1000 Grain } \\
\text { Weight }(\mathrm{g})\end{array}$ & $\begin{array}{c}\text { Grain Yield } \\
(\mathrm{kg} \mathrm{ha})\end{array}$ \\
\hline Replicate & 3 & 1.525 & 1699.00 & 21.142 & 0.042 & 14199.74 \\
Subjects & 3 & 2.951 & 6673.00 & 14.585 & $4.279^{*}$ & $6939.13^{*}$ \\
Error & 9 & 6.371 & 2581.44 & 13.869 & 0.654 & 1325.10 \\
CV $(\%)$ & & 2.25 & 6.22 & 4.74 & 1.90 & 3.18 \\
\hline
\end{tabular}

*: statistically significant at 0.05 level, **: statistically significant at 0.01 level

Table 4 Effect of applications on plant height, number of spikes, 1000 seeds weight, hectoliter weight and yield values in Dogankent location.

\begin{tabular}{l|ccccc}
\hline Application & Plant Height $(\mathrm{cm})$ & $\begin{array}{c}\text { Number of Spikes } \\
\left(\text { piece } \mathrm{m}^{-2}\right)\end{array}$ & $\begin{array}{c}\text { Hektoliter Weight } \\
(\mathrm{kg})\end{array}$ & $\begin{array}{c}\text { 1000 Grain } \\
\text { Weight }(\mathrm{g})\end{array}$ & $\begin{array}{c}\text { Grain Yield } \\
(\mathrm{kg} \mathrm{ha})\end{array}$ \\
\hline Control & 111.2 & 777 & 76.9 & $42.5 \mathrm{~b}$ & $10920 \mathrm{c}$ \\
$500 \mathrm{ml} / \mathrm{t}$ & 112.6 & 872 & 81.2 & $43.5 \mathrm{a}$ & $11900 \mathrm{a}$ \\
$1 \mathrm{l} / \mathrm{t}$ & 112.9 & 797 & 78.6 & $41.6 \mathrm{~b}$ & $11290 \mathrm{bc}$ \\
$1.5 \mathrm{l} / \mathrm{t}$ & 111.4 & 818 & 77.4 & $41.1 \mathrm{~b}$ & $11580 \mathrm{ab}$ \\
Average & 112.02 & 816 & 78.52 & 42.17 & 11420 \\
LSD $(0.05)$ & $\mathrm{ns}$ & $\mathrm{ns}$ & $\mathrm{ns}$ & 1.29 & 582.2 \\
\hline \multicolumn{2}{l}{ ns: non-significant } & & & &
\end{tabular}

Statistically significant differences were found in 1000 grain weight and yield due to applications in the Dogankent location (Table 4). The highest 1000 grain weight $(43.5 \mathrm{~g})$ was obtained from the $500 \mathrm{ml} \mathrm{t}^{-1}$ application dose (Table 4).

The highest yield was obtained from $500 \mathrm{ml} \mathrm{t}^{-1}$ application dose. Yield increase was $8,97 \%$ compared to control parcel by $500 \mathrm{ml} \mathrm{t}^{-1}$ application dose (Figure 1). There was no statistically significant effect on the number of spikes per square meter and the hectoliter weight. However, the highest values were taken from the $500 \mathrm{ml}$ $\mathrm{t}^{-1}$ application dose (Table 4). In recent years, many researches was carried out on different seed coating methods against environmental stress conditions. Several studies was reported satisfactory effects of seed coating on seed germination, seedling growth, root and shoot growth, leaf area, biomass and yield (Zelonka et al., 2005; Gevrek et al., 2012; Tavares et al., 2013). In addition, seed coating reduces dust formation and leaching of insecticides from treated seed during sowing (Avelar et al., 2012).

Seed coating with microbial consortium based on the arbuscular mycorrhizal fungus Glomus intraradices, Glomus mossae and Trichoderma atroviride were assessed by Colla et al. (2015). In the open field trials, use of the uncoated seeds led to a significant reduction in grain yield by $24.3 \%$ and $7.7 \%$, during the first and second growing season, respectively, compared to the coated seeds.

Film-coating barley seeds with free and immobilized alkaline phosphatase was investigated by Pilar-Izquierdo et al. (2012). Film-coating significantly increased the phosphatase activity in the rhizosphere and the $\mathrm{P}$ uptake by plants.

In a seed coating experiment with $\mathrm{Zn}$ containing formulations of 'Teprosyn-ZnP' or 'Teprosyn-Zn', applications effectively corrected $\mathrm{Zn}$ deficiencies and improved growth and grain yield of wheat, soybean, sunflower, maize and peanut (Singh, 2007).

In a study of Bhaskara Reddy et al. (1999), Chitosan treatment $\left(2-8 \mathrm{mg} \mathrm{ml}^{-1}\right)$ of wheat seeds significantly improved seed germination and vigor at concentrations $>4$ $\mathrm{mg} \mathrm{ml}$, in two cultivars of spring wheat. Synthesis of phenolic acids and lignin was stimulated in leaves following chitosan treatment. Chitosan also inhibited fungal transmission to the primary roots of germinating seedlings. 
Grain Yield (kg/ha)

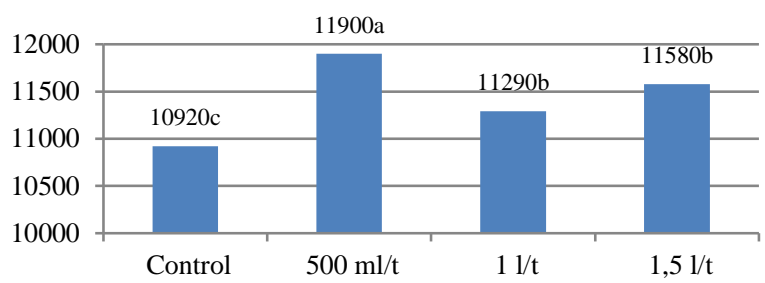

Figure 1 Effect of applications on grain yield values in Dogankent location
Grain Yield (kg/ha)

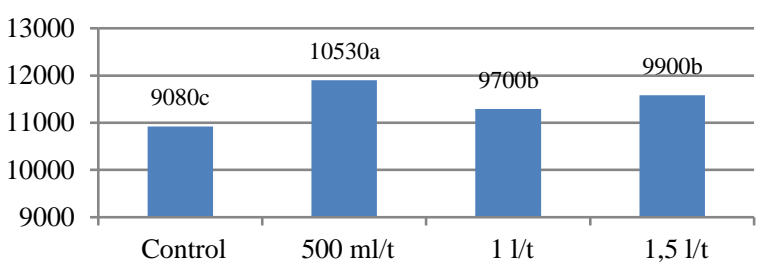

Figure 2 Effect of applications on yield values in Haciali location

Table 5 Varience analysis of applications in Haciali location (Mean Square)

\begin{tabular}{l|cccccc}
\hline \multicolumn{1}{c|}{ Source } & DF & $\begin{array}{c}\text { Plant Height } \\
(\mathrm{cm})\end{array}$ & $\begin{array}{c}\text { Number of Spikes } \\
\left(\text { piece } \mathrm{m}^{-2}\right)\end{array}$ & $\begin{array}{c}\text { Hektoliter Weight } \\
(\mathrm{kg})\end{array}$ & $\begin{array}{c}\text { 1000 Grain } \\
\text { Weight }(\mathrm{g})\end{array}$ & $\begin{array}{c}\text { Grain Yield } \\
\left.(\mathrm{kg} \mathrm{ha})^{-1}\right)\end{array}$ \\
\hline Replicate & 3 & 18.416 & 1498.00 & 21.172 & 0.255 & 294.643 \\
Subjects & 3 & 29.712 & $18010.0^{*}$ & 31.268 & $1.736^{* *}$ & $14283.5^{* *}$ \\
Error & 9 & 22.867 & 4081.78 & 8.288 & 0.205 & 1007.79 \\
CV $(\%)$ & & 4.77 & 7.85 & 3.64 & 1.04 & 3.23 \\
\hline
\end{tabular}

*: statistically significant at 0.05 level, **: statistically significant at 0.01 level

Table 6 Effect of applications on plant height, number of spikes, 1000 seeds weight, hectoliter weight and yield values in the Haciali location

\begin{tabular}{l|ccccc}
\hline Application & $\begin{array}{c}\text { Plant Height } \\
(\mathrm{cm})\end{array}$ & $\begin{array}{c}\text { Number of Spikes } \\
\left(\text { piece } \mathrm{m}^{-2}\right)\end{array}$ & $\begin{array}{c}\text { Hektoliter Weight } \\
(\mathrm{kg})\end{array}$ & $\begin{array}{c}1000 \text { Grain Weight } \\
(\mathrm{g})\end{array}$ & $\begin{array}{c}\text { Grain Yield } \\
\left(\mathrm{kg} \mathrm{ha}^{-1}\right)\end{array}$ \\
\hline Control & 102.4 & $727 \mathrm{~b}$ & 75.2 & $42.7 \mathrm{c}$ & $9080 \mathrm{c}$ \\
$500 \mathrm{ml} / \mathrm{t}$ & 100.3 & $889 \mathrm{a}$ & 81.6 & $44.2 \mathrm{a}$ & $10530 \mathrm{a}$ \\
$1 \mathrm{l} / \mathrm{t}$ & 101.7 & $830 \mathrm{a}$ & 80.5 & $43.6 \mathrm{ab}$ & $9700 \mathrm{~b}$ \\
$1.5 \mathrm{l} / \mathrm{t}$ & 96.3 & $808 \mathrm{ab}$ & 78.7 & $43.0 \mathrm{bc}$ & $9900 \mathrm{~b}$ \\
Average & 100.2 & 814 & 79.0 & 43.37 & 9800 \\
LSD $(0.05)$ & $\mathrm{ns}$ & 102.19 & $\mathrm{~ns}$ & 0.72 & 50.78 \\
\hline
\end{tabular}

ns: non-significant

In Ethiopia, 12 different seed-coating products were tested on bread wheat in 2014 by Wolie et al. (2017). Statistically significant differences were found in number of grains and grain yield after applications in this study. The highest number of grains (56.52 grains spike $\left.{ }^{-1}\right)$ and grains yield $\left(4.70 \mathrm{tha}^{-1}\right)$ were obtained from the pesticide + biocide seed coating application.

Five different fungicide seed coating applications were conducted on a winter wheat variety in 26 different locations in western Canada between 2011 and 2013 years by Turkington et al. (2016). Fungicide seed coating application was reported to increase grain yield and net income.

In Haciali location, the effect of organic acid mixture applications on plant height and hectolitre weights were statistically insignificant. Applications resulted with significant differences in the number of spikes $\mathrm{m}^{-2}, 1000$ grain weight and yield with statistical significance of 0.05. Differences were subjected to the LSD test and are given in Table 5, 6 .

The highest yield increase was obtained from $500 \mathrm{ml} \mathrm{t}^{-1}$ organic acid mixture application and this yield increase was $15.96 \%$ higher compared to the control plots (Table 6 and Figure 2). The total amount of rainfall during the wheat growing season in Haciali location is lower than Dogankent location (Table 2). However, the effect of organic acid mixture on yield was higher in Haciali location. Effect of $500 \mathrm{ml} \mathrm{t}^{-1}$ organic acid mixture application on the yield criterias such as number of spikes per square meter and 1000 grain weight was more significant than other applications. With $500 \mathrm{ml} \mathrm{t}^{-1}$ organic acid mixture application, the highest number of spikes and 1000 grains weight were determined as 889 piece $\mathrm{m}^{-2}$ and 44,2 $\mathrm{g}$, respectively (Table 6). This may be sourced from biochemical changes in the structure of the seeds after seed priming, such as activation of enzymes effecting germination and stand establishment. Jafar et al. (2012) reported that osmopriming seeds with $\mathrm{CaCl}_{2}$ followed by ascorbate priming treatments enhanced carbohydrate metabolism and assimilate translocation. All these factors might explain the higher grain yield in treatment compared to control conditions. However, Giri and Schillinger (2003) reported that none of the tested seed priming media effected field emergence or subsequent grain yield of wheat cultivars compared to the control.

A seed coating study was carried out in bread wheat in the north west of the USA. The highest yield values for used both varieties in the study were obtained from the "zinc and manganese + organic acid mixture product $(0.75 \%$ citric acid, $0.25 \%$ glutamate, $0.25 \%$ proline, $2 \%$ $\mathrm{Zn}$ and 96.75 water)" application during the 2015-2016 season. "zinc and manganese + organic acid mixture product $(0.75 \%$ citric acid, $0.25 \%$ glutamate, $0.25 \%$ proline, $2 \% \mathrm{Zn}$ and 96.75 water)" application resulted in yield increase of $11.9 \%$ compared to control (Walsh et al., 2016). 
Table 7 Variance analysis of applications in Dogankent location (Mean Square)

\begin{tabular}{l|ccccc}
\multicolumn{1}{c|}{ Source } & DF & Protein(\%) & Gluten $(\%)$ & Hardness $(\%)$ & Sedimentation(ml) \\
\hline Replicate & 3 & 0.041 & 0.437 & 0.190 & 3.668 \\
Subjects & 3 & 0.091 & 0.436 & 0.067 & 3.574 \\
Error & 9 & 0.060 & 0.887 & 0.134 & 5.373 \\
CV $(\%)$ & & 1.84 & 2.92 & 1.61 & 4.78 \\
\hline$*$ : & & & &
\end{tabular}

*: statistically significant at 0.05 level, $* *$ : statistically significant at 0.01 level

Table 8 Effect of applications on protein, gluten, hardness and sedimentation values in Dogankent location

\begin{tabular}{l|cccc}
\multicolumn{1}{c|}{ Application } & Protein $(\%)$ & Gluten $(\%)$ & Hardness $(\%)$ & Sedimentation $(\mathrm{ml})$ \\
\hline Control & 13.17 & 31.83 & 59.63 & 47.34 \\
$500 \mathrm{ml} / \mathrm{t}$ & 13.35 & 32.27 & 59.57 & 48.42 \\
$11 / \mathrm{t}$ & 13.28 & 31.95 & 59.44 & 48.36 \\
$1.5 \mathrm{l} / \mathrm{t}$ & 13.53 & 32.56 & 59.44 & 49.65 \\
Average & 13.33 & 32.15 & 59.52 & 48.44 \\
LSD $(0.05)$ & $\mathrm{ns}$ & $\mathrm{ns}$ & $\mathrm{ns}$ & $\mathrm{ns}$ \\
\hline ns: non-significant & & & &
\end{tabular}

Table 9 Variance analysis of applications in Haciali location (Mean Square)

\begin{tabular}{l|ccccc}
\hline \multicolumn{1}{c|}{ Source } & DF & Protein $(\%)$ & Gluten $(\%)$ & Hardness $(\%)$ & Sedimentation $(\mathrm{ml})$ \\
\hline Replicate & 3 & 0.054 & 0.434 & 0.885 & 3.916 \\
Subjects & 3 & 0.007 & 0.085 & 0.418 & 2.412 \\
Error & 9 & 0.058 & 0.821 & 0.246 & 2.989 \\
CV $(\%)$ & & 1.85 & 2.68 & 1.76 & 3.28 \\
\hline
\end{tabular}

*: statistically significant at 0.05 level, $* *$ : statistically significant at 0.01 level

Table 10 Effect of applications on protein, gluten, hardness and sedimentation values in Haciali location

\begin{tabular}{l|cccc}
\hline \multicolumn{1}{c|}{ Application } & Protein $(\%)$ & Gluten $(\%)$ & Hardness $(\%)$ & Sedimentation $(\mathrm{ml})$ \\
\hline Control & 12.97 & 33.59 & 64.92 & 53.36 \\
$500 \mathrm{ml} / \mathrm{t}$ & 13.01 & 33.92 & 65.20 & 53.14 \\
$1 \mathrm{l} / \mathrm{t}$ & 12.91 & 33.63 & 64.71 & 52.34 \\
$1.5 \mathrm{l} / \mathrm{t}$ & 12.99 & 33.75 & 64.44 & 51.66 \\
Average & 12.97 & 33.72 & 64.81 & 52.62 \\
LSD $(0.05)$ & $\mathrm{ns}$ & $\mathrm{ns}$ & $\mathrm{ns}$ & $\mathrm{ns}$ \\
\hline
\end{tabular}

ns: non-significant

In seed quality analysis after harvest conducted in the quality laboratory of Eastern Mediterranean Agricultural Research Institute showed that the effects of organic acid mixture applications on wheat protein, gluten, hardness and sedimentation properties were not statistically significant. The quality results at Dogankent and Haciali locations are given below in Tables 7, 8, 9 and 10. In the Dogankent location, the average protein ratio was higher but the gluten, hardness and sedimentation values were lower than the Haciali location (Tables 8 and 10).

\section{Conclusion}

Effects of seed coating with organic acid mixture at different doses on wheat yield, yield and quality characteristics were investigated by the experiments carried out in Dogankent and Haciali locations of Eastern Mediterranean Agricultural Research Institute in Turkey.

As a result of the research, the best yield results were obtained from the application of $500 \mathrm{ml} \mathrm{t}^{-1}$ "Take Off St" in both trial locations. The application of organic acid mixture at $500 \mathrm{ml} \mathrm{t}^{-1}$ provided a yield increase of $8.97 \%$ in Dogankent location and $15.96 \%$ at the Haciali location compared to the control parcels. Total amount of rainfall during the wheat growing season in Haciali location was lower than Dogankent location but the effect of organic acid mixture on yield was higher in Haciali location. This indicates that the effects of such plant nutrition products on stress conditions may be more evident. For this reason, such studies is needed to be conducted in different regions and with different plants species. No effect of the product was observed on quality criteria's.

\section{References}

Anonymus. 2018. Brand label of "Take off ST" (www.vlsci.com/assets/dl/Specimen-Label-REV-07-16-B0GHS-Pending-CA.pdf). Access date: 26.07.2018

Avelar SAG, FVS G. Fiss, L Baudet, and ST Peske. 2012. The use of film coating on the performance of treated corn seed. Revista Brasileira de Sementes 34:186-192.

Bhaskara Reddy, MV, Arul J, Angers P, Couture L. 1999. Chitosan treatment of wheat seeds induces resistance to Fusarium graminearum and improves seed quality. Journal of Agricultural and Food chemistry, 47(3): 1208-1216.

Bouyoucous GJ. 1952. Hydrometer method improved for making particle size at analysis of soil. Agronomy journal, 54(5): 464-465.

Calvo P, Nelson L, Kloepper JW. 2014. Agricultural uses of plant biostimulants. Plant Soil, 383: 3-41.

Campbell B. 2010. Organic matter application can reduce copper toxicity in tomato plants. Journal of Natural Resources \& Life Sciences Education, 39(1): 45-48. 
Colla G, Rouphael Y, Bonini P, Cardarelli M. 2015. Coating seeds with endophytic fungi enhances growth, nutrient uptake, yield and grain quality of winter wheat. Int. J. Plant Prot, 9, 171-89.

Du Jardin P. 2015. Plant biostimulants: Definition, concept, main categories and regulation. Sci. Hort., 196: 3-14.

El Sayed SA, Hellal FA, Matter FMA, Mahfouz SA. 2015. Micronutrient and compost induced changes of growth, yield, nutrient and phytochemical content of canola grown in saline soil. American-Eurasian Journal of Sustainable Agriculture, 16-23.

FAO. 2016. Food and Agriculture Organization of the United Nations. http://faostat3.fao.org/home/E (Acces. date:15.08.2016)

Ferreyra R, Peralta J, Sadzawka A, Valenzuela J, Munoz C. 1998. Effect of acid application on some chemical characteristics of a calcareous soil. Agricultura Técnica (Chile).

Gevrek MN, Atasoy GD, Yigit A. 2012. Growth and yield response of rice (Oryza sativa L.) to different seed coating agents. Int. J. Agric. Biol. 14:826-830

Giri GS and Schillinger WF. 2003.Seed Priming Winter Wheat for Germination, Emergence, and Yield. Crop Science 43: 2135-2141.

Jackson ML. 1959. Soil chemical analysis. Englewood Cliffs, New Jersey.

Jafar MZ, Farooq M, Cheema MA, Afzal I, Basra SMA, Wahid MA, Aziz T, Shahid M. 2012. Improving the Performance of Wheat by Seed Priming Under Saline Conditions. Journal Agron Crop Science 198: 38-45.

Martinez-Pacheco MM, Flores-Garcia A, Venegas-Gonzalez E, Cepeda-Villegas MA. 2011. Effect of citric acid on the proteolytic activity of Zea mays L. Ciência e Agrotecnologia, 35(5): 908-915.

Olsen SR, Cole CV, Watanabe FS, Dean LA. 1954. Estimation of available phosphorus in soil by extraction with sodium bicarbonate. USDA Circ., 939. U.S. Cov. Print Office, Washington D.C.

Pedrini S, Merritt DJ, Stevens J, Dixon K. 2017. Seed coating: science or marketing spin?. Trends in plant science, 22(2): 106-116.

Pilar-Izquierdo MC, Ortega N, Perez-Mateos M, Busto MD. 2012. Barley seed coating with free and immobilized alkaline phosphatase to improve $\mathrm{P}$ uptake and plant growth. The Journal of Agricultural Science, 150(6): 691701.

Sadak MS, Elhamid, EMA, Mostafa, HM. 2013. Alleviation of adverse effects of salt stress in wheat cultivars by foliar treatment with antioxidants I. changes in growth, some biochemical aspects and yield quantity and quality. Am-Eur. J. Agric. Environ. Sci, 13, 1476-1487.
Sánchez-Rodríguez AR, Del Campillo MC, Torrent J, Jones DL. 2014. Organic acids alleviate iron chlorosis in chickpea grown on two P-fertilized soils. Journal of Soil Science and Plant Nutrition, 14(2), 292-303.

Seadh SE, EL-Abady MI, Farouk S, EL-Saidy Amal EA. 2008. Effect of foliar nutrition with humic and amino acids under $\mathrm{N}$-levels on wheat productivity and quality of grains and seeds. Egypt. J. Appl. Sci., 23: 543-558.

Singh MV. 2007. Efficiency of seed treatment for ameliorating zinc deficiency in crops. Zinc crops, 24-26.

Ström L, Owen AG, Godbold DL, Jones DL. 2005. Organic acid behaviour in a calcareous soil implications for rhizosphere nutrient cycling. Soil Biology and Biochemistry, 37(11): 2046-2054.

Subbarao GV, Wheeler RM, Levine LH, Stutte GW. 2001. Glycine betaine accumulation, ionic and water relations of red-beet at contrasting levels of sodium supply. Journal of Plant Physiology, 158(6): 767-776.

Tabuchi M, Abiko T, Yamaya T. 2007. Assimilation of ammonium ions and reutilization of nitrogen in rice (Oryza sativa L.). Journal of experimental botany, 58(9): 23192327.

Tavares LC, Rufino CA, Brunes AP, Friedrich FF, Barros A.C.S.A, Villela FA. 2013. Physiological performance of wheat seeds coated with micronutrients. Journal of Seed Science 35:2834.

Turkington T K, Beres BL, Kutcher HR, Irvine B, Johnson EN, O 'Donovan JT, Stevenson F C. 2016. Winter wheat yields are increased by seed treatment and fall-applied fungicide. Agronomy Journal, 108(4): 1379-1389.

US Salinity Laboratory Staff. 1954. Diagnosis and İmprovement of, Saline and Alkaline Soils (Ed L. A. Richards). USDA Agriculture Handbook B, No: 60, U. S. Gov. Printing Office, Washington, $160 \mathrm{P}$.

Walch-Liu P, Liu LH, Remans T, Tester M, Forde BG. 2006. Evidence that L-glutamate can act as an exogenous signal to modulate root growth and branching in Arabidopsis thaliana. Plant and Cell Physiology, 47(8): 1045-1057.

Walsh O, McClintick-Chess J, MBlanscet S. 2016. Evaluation of seed Coating Treatments in Soft White Winter Wheat. ASA, CSSA and SSSA İnternational Annual Meeting. Poster number: 468-429.

Wolie AW, Zewudie DA, Feleke TT. 2017. Evaluation of seed priming and coating on emergence, yield and yield components of bread wheat (Triticum aestivum L.) in Northwest Ethiopia. Ethiopian Journal of Science and Technology, 10(2): 123-136.

Yari L, Khazaei F, Sadeghi H, Sheidaei S. 2011. Effect of seed priming on grain yield and yield components of bread wheat (Triticum aestivum L.). J. Agr. Biol. Sci 6: 1-5.

Zelonka L, Stramkale V, Vikmane M. 2005. Effect and aftereffect of barley seed coating with phosphorus on germination, photosynthetic pigments and grain yield. Acta Univ. Latviensis, Biology, pp. 691:111-119. 